\title{
The effect of disturbance caused by rivers flooding on ground beetles (Coleoptera: Carabidae)
}

\author{
PAwEe SIENKIEWICZ ${ }^{1}$ and Michat ŻMIHORSKI ${ }^{2 *}$ \\ ${ }^{1}$ Department of Entomology and Environmental Protection, Poznań University of Life Sciences, Dą̧rowskiego 159, 60-594 Poznań, \\ Poland \\ ${ }^{2}$ Museum and Institute of Zoology, Polish Academy of Sciences, Wilcza 64, 00-679 Warsaw, Poland; \\ e-mail: zmihorski@miiz.waw.pl
}

Key words. Carabidae, floodplain, flooding, disturbance, ground beetles, river ecology, biodiversity

\begin{abstract}
We studied the effect of flooding on a carabid community inhabiting grassland in a large river valley (W Poland). We used pitfall-traps to catch beetles from April to November 1999-2001. Some of the samples collected were preceded by floods during the collecting period, which enabled us to evaluate the effects of flooding on species composition and abundance. We collected 17,722 individuals belonging to 108 species. The number of species and individuals per sample differed between plots and showed a nonlinear decrease over time, from spring to autumn. Carabids were more abundant in samples collected after floods than in the control samples. In contrast, the expected cumulative number of species as a function of the number of individuals collected was lower in samples collected after floods than in the control samples. In the case of the most abundant species the species-specific responses in terms of the numbers caught after flooding differed, with those of (e.g. Agonum micans) increasing and those of (Amara plebeja, Epaphius secalis) decreasing. This study shows that floods filter the community with the result that some species increase in abundance but the overall species richness decreases. Therefore natural floods are important in shaping the structure of communities of epigeic carabids on floodplains.
\end{abstract}

\section{INTRODUCTION}

Floods are one of the most important natural disturbing agents of terrestrial ecosystems in lowland Europe (Bornette \& Amoros, 1996). Compared to other natural disturbances, such as wildfires or hurricanes, floods occur more frequently and the total area affected is relatively large. The consequences of fluvial dynamics distinctly change the functioning of ecosystems adjacent to rivers, as the duration, magnitude, frequency and deposition of sediments shape the physical habitat, which in turn affects animal communities (Girel, 1994; Rotenbücher \& Schaeffer, 2005, 2006). Flooding causes an increase in the trophy of the whole ecosystem as a large biomass of sediments is taken from the main stream and deposited on the floodplain. Moreover, floods create new habitats (e.g. sand dunes) and seem to promote habitat mosaics by creating temporal water bodies located out of the main stream of the river (Girel, 1994; Ward et al., 2001; Tockner \& Stanford, 2002). Floods during winter, when ice flows occur, can lead to severe destruction of riparian vegetation and death of woody plants. This, together with a temporal increase in humidity in flooded areas, can cause an increase in the biomass of vegetation. As a consequence a long term effect of floods can be an overall increase in animal species richness (Walter et al., 1998; Tockner \& Stanford, 2002; Andersen \& Hanssen, 2005; Plum, 2005).

Riparian vegetation provides specific and rare habitats, including river banks, species-rich forests, sand dunes etc. associated with rivers, especially those that are unregulated and with adjacent floodplains, which can be biodiversity hotspots (Plum, 2005; Romanowski et al., 2005). Therefore, it is assumed that the carabid communities in these habitats are rich in species. On the other hand, the dynamics of the system with dramatic changes in water level would appear to be highly unfavorable for strictly terrestrial species that avoid highly humid habitats (Thiele, 1977; Beyer \& Grube, 1997; Luka et al., 2009). This is especially the case for those species that are flightless and therefore vulnerable during flooding and the expectation is that such species are less abundant close to rivers. Therefore, the final outcome of flooding at the community level is determined by the ratio of winners-tolosers, i.e. the proportions of species that increase and decrease in number in response to the disturbance. The proportion seems to depend on the species composition of the local community and habitat characteristics (e.g. availability of safe refugia).

A knowledge of the effect of flooding on species richness and abundance of particular groups of organisms is crucial for evaluating the biological effects of river regulation in terms of biodiversity conservation (Plum, 2005; Rotenbücher et al., 2005; Jensen et al., 2006). Flooding is an important component of the fluvial dynamics of unregulated rivers. However, the regulation of rivers by substantially changing the riverbanks is commonly enforced in many countries. This indicates an inadequate understanding of aquatic ecosystem dynamics. Therefore,

\footnotetext{
* Corresponding author.
} 


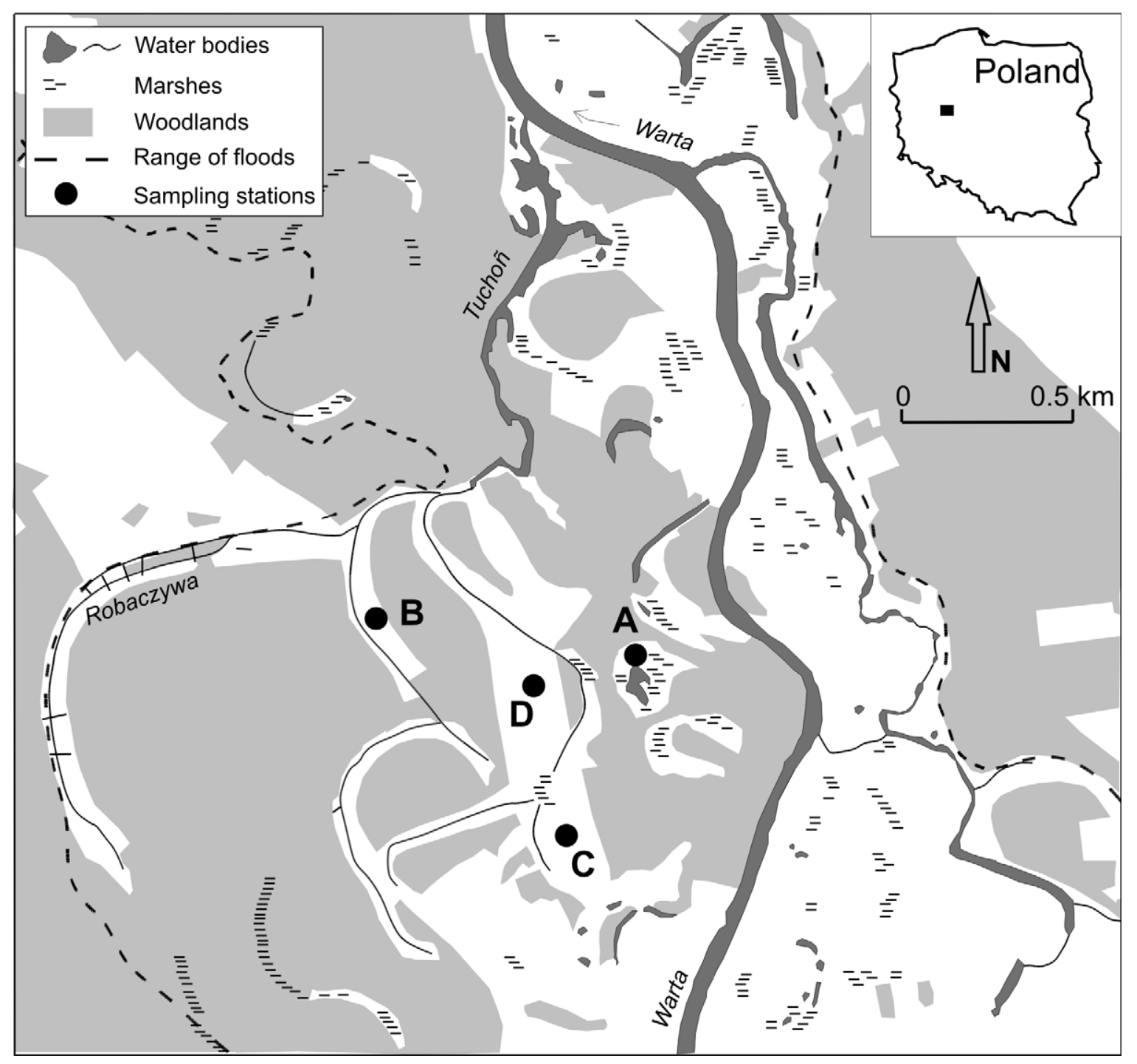

Fig. 1. Location of the sites where the samples were collected.

a more comprehensive knowledge of the ecological effect of flooding is needed and should form a crucial part of an evidence-based management policy. Despite this, the effect of flooding on several taxonomic groups is rather poorly understood and little is known about the importance of natural fluvial dynamics for riparian epigeic arthropods (Ellis et al., 2001; Paetzold et al., 2008).

In this paper we address the effects of flooding on epigeic invertebrates, namely carabid beetles. Ground beetles constitute a species-rich taxon with an important biocenotic role in ecosystems and are commonly used as bioindicators (Koivula, 2011; Kotze et al., 2011 and references therein). More specifically, we investigated the changes that occur in a grassland carabid community, both in terms of abundance and species composition, after flooding. We hypothesize that flooding dramatically changes both the abundance and species composition of the community of carabids mainly by forcing ground beetles to leave flooded areas. More specifically, we expect that there is a decrease in the general abundance and species richness of the whole community following flooding as the majority of the species are epigeic and avoid water.
However, bearing in mind that some carabids can survive flooding (Gerisch, 2011) it is likely that some species will increase in abundance after floods. Therefore, we assume that after flooding there will be both winners and losers.

\section{METHODS}

\section{Study area}

This study was carried out in the Warta River valley, W Poland (52 $\left.11^{\prime} 26^{\prime \prime} \mathrm{N}, 16^{\circ} 59^{\prime} 13^{\prime \prime} \mathrm{E}\right)$ within the Nature 2000 site "Rogalińska Dolina Warty". The study area includes a well preserved natural river valley with various types of riparian vegetation and adjacent meadows (Fig. 1). Despite some regulation of the watercourse, natural floods occur mainly in spring and summer. The floods cover extensive areas adjacent to the river and can extend as far as $2 \mathrm{~km}$ from the riverbank. However, the extent of the flood depends on the current water level and local topography. What is important for most of the entomofauna is that the change in the water level is relatively fast and can exceed $1 \mathrm{~m}$ in $24 \mathrm{~h}$. As a consequence, the proportion of the floodplain remaining under water also changes. Therefore, the great variation in the level of the water and the area flooded can affect qualitative and quantitative characteristics of the epigeic fauna. During the study period we recorded 11 separate floods, 
TABLE 1. Summary of the two generalized additive mixed models (GAMM) explaining the number of individuals and number of species of carabids in the 237 samples collected in the Warta river valley, W Poland, in 1999-2001. Test statistics and p-values are given for each estimate of a predictor parameter (B). Share of variability of the dependent variables explained by each model is presented as $\mathrm{R}_{\text {adj. }}^{2}$

\begin{tabular}{|c|c|c|c|c|c|c|}
\hline \multirow{2}{*}{ Predictor } & \multicolumn{3}{|c|}{$\mathrm{N}$ of individuals $\left(\mathrm{R}_{\text {adj }}^{2}=0.275\right)$} & \multicolumn{3}{|c|}{$\mathrm{N}$ of species $\left(\mathrm{R}_{\text {adj }}^{2}=0.466\right)$} \\
\hline & $\mathrm{B}( \pm \mathrm{SE})$ & statistic & $\mathrm{p}$-value & $\mathrm{B}( \pm \mathrm{SE})$ & statistic & p-value \\
\hline Intercept & $4.47(0.096)$ & 46.31 & $<0.0001$ & $2.67(0.054)$ & 48.99 & $<0.0001$ \\
\hline Flood $=$ After Flood & $0.35(0.160)$ & 2.18 & 0.0301 & $0.02(0.098)$ & 0.24 & 0.8103 \\
\hline Flood $=$ Control & 0 & & & 0 & & \\
\hline Plot $=\mathrm{D}$ & $-0.51(0.140)$ & -3.66 & 0.0003 & $-0.26(0.078)$ & -3.32 & 0.0010 \\
\hline Plot $=\mathrm{C}$ & $-0.52(0.140)$ & -3.71 & 0.0003 & $-0.17(0.075)$ & -2.26 & 0.0248 \\
\hline Plot $=\mathrm{B}$ & $-0.48(0.150)$ & -3.24 & 0.0014 & $-0.19(0.081)$ & -2.40 & 0.0173 \\
\hline Plot $=\mathrm{A}$ & 0 & & & 0 & & \\
\hline Spline(Day) & $\mathrm{df}=3.66$ & 17.67 & $<0.0001$ & $\mathrm{df}=4.14$ & 40.42 & $<0.0001$ \\
\hline
\end{tabular}

which occurred in May, July, August and October. At the nearby water measuring station on the Warta River the average depth of the water was $180 \mathrm{~cm}$ whereas during the floods in 1999-2001 it increased to ca. 280-300 cm. During the floods the plots studied were under water to a depth of ca. $15-20 \mathrm{~cm}$.

We sampled four plots on the flood plain of the River Warta. The sites were ca. 300-600 m apart and covered with grass, which was mowed 1-2 times per year. The plots differed slightly in terms of the abiotic conditions. Soil moisture changed somewhat from plot A, which was the wettest to plot B the driest. More detailed descriptions of the habitat characteristics and plant species in the plots is given in Sienkiewicz (2003) and Sienkiewicz \& Konwerski (2004).

\section{Sampling}

The samples were collected in 1999-2001 (for plots A, B and C) and 2000-2001 (for plot D). We used pitfall-traps, $18 \mathrm{~cm}$ in diameter and $14 \mathrm{~cm}$ deep. At each plot 9 traps were placed every $2 \mathrm{~m}$ along a linear transect. The traps were filled with ethylene-glycol and detergent to reduce surface tension. The glycol was replaced at least every month. The traps were emptied every 7-10 days from the beginning of April till midNovember, except during flooding.

Individuals from all 9 traps from one plot were pooled and treated as one sample. As a result, we collected 237 samples among which 231 contained at least one individual Carabid. The samples were used as replications in further statistical analyses. For each sample we noted whether the plot was flooded during the 20 days prior to when the sample was collected. As a result we divided all the samples into those collected just after flooding and those that had not been subjected to a previous flooding event. Hereafter the samples are divided in respect to previous flooding into two groups (After flood or Control).

A full list of species recorded is not presented here as it is published in Sienkiewicz (2003) and Sienkiewicz \& Konwerski (2004) and is available on request from the corresponding author.

\section{Statistical analysis}

We used generalized additive mixed models (GAMM) to explain the variability in the number of individuals and the number of species in samples in relation to four predictors. In the modeling we used Year as random categorical factor, Plot $(\mathrm{A} / \mathrm{B} / \mathrm{C} / \mathrm{D})$ and previous flooding (Flood = After Flood vs. Control) as fixed categorical factors, and Day of year as covariate fitted with spline. We used GAMM with quasi-Poisson error distribution and a log link function. We produced separate models for the number of individuals and number of species, respectively. For this purpose we used "mgcv" package (Wood, 2004) in R program (R Development Core Team, 2011).

In order to compare species diversity in samples collected after flooding and in the control samples we used rarefaction curves implemented in EstimateS 8.0.0. software (Colwell, 2005). The curves estimate the expected cumulative number of species in relation to the number of individuals sampled (i.e. individual-based Coleman rarefaction), which should be interpreted as a measure of species diversity with controlled sampling effort. Moreover, to compare species richness in the two groups of samples we used Chaol estimator of total species richness (with 95\% confidence intervals), which assesses the number of unseen species in samples (i.e. species not caught by the traps although present in the study area, Colwell, 2005).

Next we attempted to select the factors determining the overall variability of the community. For this purpose the variability of the whole community was addressed using the detrended correspondence analysis (DCA) in Canoco 4.5. Then we used the position of each sample along the four axes of the DCA as response variables in a MANOVA, in which Flood, Year, Plot and Day were included as explanatory variables. We did not include interaction terms. This analysis enabled us to determine the most important factors affecting the variation of the whole community.

Finally, we described a species-specific response to flooding by comparing the abundance of the 30 most common (i.e. those with a total abundance exceeding 100 individuals) species in After Flood and Control samples. We carried out this comparison using 30 independent GLMs with quasi-Poisson error distributions and with Flood, Year, Plot and Day used as explanatory variables. For each species we presented the exponentiated parameter estimates of the Flood factor along with its $95 \%$ confidence intervals. The GLMs were implemented in R (R Development Core Team, 2011).

\section{RESULTS}

\section{Species composition}

In total, we collected 17,722 individuals of Carabids belonging to 108 species. The mean number of individuals and species in a sample denoted $74.8(\mathrm{SD}=78.9)$ and 13.6 $(\mathrm{SD}=7.9)$, respectively. The number of species per sample ranged from $16(\mathrm{SD}=0.2)$ in plot $\mathrm{A}$ to $12(\mathrm{SD}$ $=0.2$ ) in plot $\mathrm{D}$, whereas the number of individuals ranged from $107(\mathrm{SD}=9.5)$ in plot $\mathrm{A}$ to $61(\mathrm{SD}=6.8)$ in 

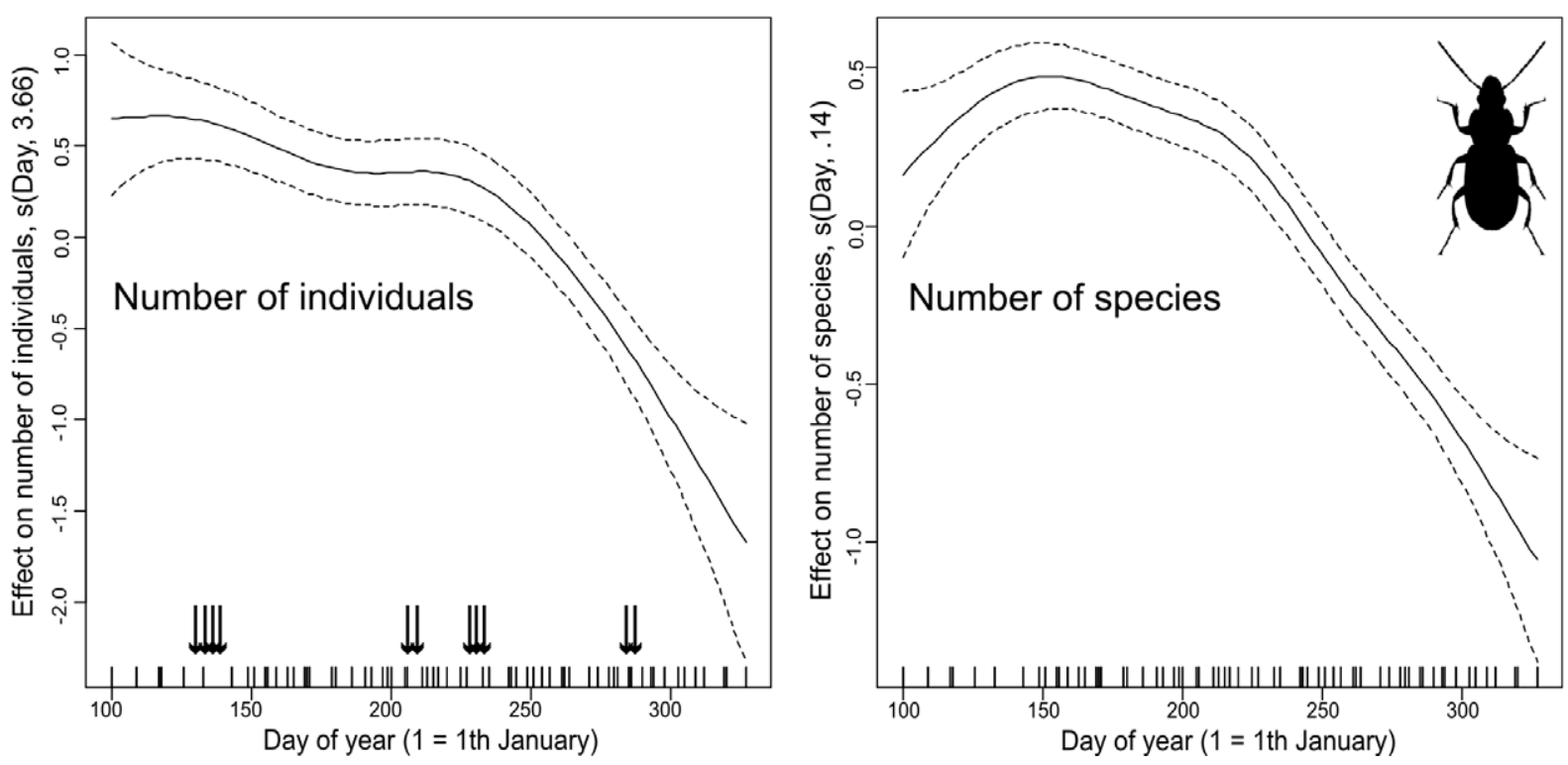

Fig. 2. Changes in the number of species and number of individuals of carabid beetles each year fitted using spline. Both fits were highly significant, see table 1 for details. In the left subplot flooding events (pooled for all years and plots) are marked with arrows.

plot C. Poecilus versicolor (Sturm) was the most abundant species ( $\mathrm{N}=1,746$ individuals), followed by Pterostichus melanarius (Ill.) $(1,402)$ and Carabus granulatus L. (1,056). Moreover, several other species were also numerous: Carabus clatratus L., Blethisa multipunctata (L.), Bembidion gilvipes Sturm, Pterostichus chamaeleon (Motsch.), Amara fulvipes (Aud.-Serv.), Stenolophus skirmshiranus Steph., Trichocellus placidus (Gall.), Limodromius longiventris (Mann.), Agonum dolens (Halb.), Oodes helopioides (Fabr.) and Patrobus septentrionis Dej. Eighteen species were represented by only one individual.

\section{Abundance and species richness}

The number of species and number of individuals in particular samples differed between plots, with both indices higher in plot $\mathrm{A}$ than in the remaining plots (Table 1). Flooding was followed by an increase in the number of individuals but species richness remained similar. Nonlinear variation in the two indices over time (from early spring to late autumn) was confirmed (Table 1, Fig. 2).

\section{Diversity}

The expected cumulative number of species differed markedly in the After Flood and Control samples. The expected number of species among the ca. 2,500 individuals sampled was by ca. 15 species higher in those samples not affected by flooding (Control) than in those collected just after a flooding event (After flood). The estimated species richness, corrected for the species absent in samples was much lower in After Flood than Control samples (Fig. 3).

\section{Similarity}

The position of particular sites along the first four axes of the Detrended Correspondence Analysis (DCA) was explained by year (MANOVA, Df $=2$, Pillai $=0.46$, approx $\mathrm{F}=16.29$, num $\mathrm{Df}=8$, den $\mathrm{Df}=442, \mathrm{P}<$
$0.0001)$, day (MANOVA, Df $=1$, Pillai $=0.65$, approx $\mathrm{F}$ $=102.11$, num $\mathrm{Df}=3$, den $\mathrm{Df}=220, \mathrm{P}<0.0001)$ and plot (MANOVA, Df $=3$, Pillai $=0.89$, approx $\mathrm{F}=23.31$, num $\mathrm{Df}=12$, den $\mathrm{Df}=666, \mathrm{P}<0.0001)$. The effect of flooding was also confirmed, but its significance was close to the threshold value (MANOVA, Df $=1$, Pillai $=$ 0.04 , approx $\mathrm{F}=2.52$, num $\mathrm{Df}=4$, den $\mathrm{Df}=220, \mathrm{P}=$ $0.0423)$.

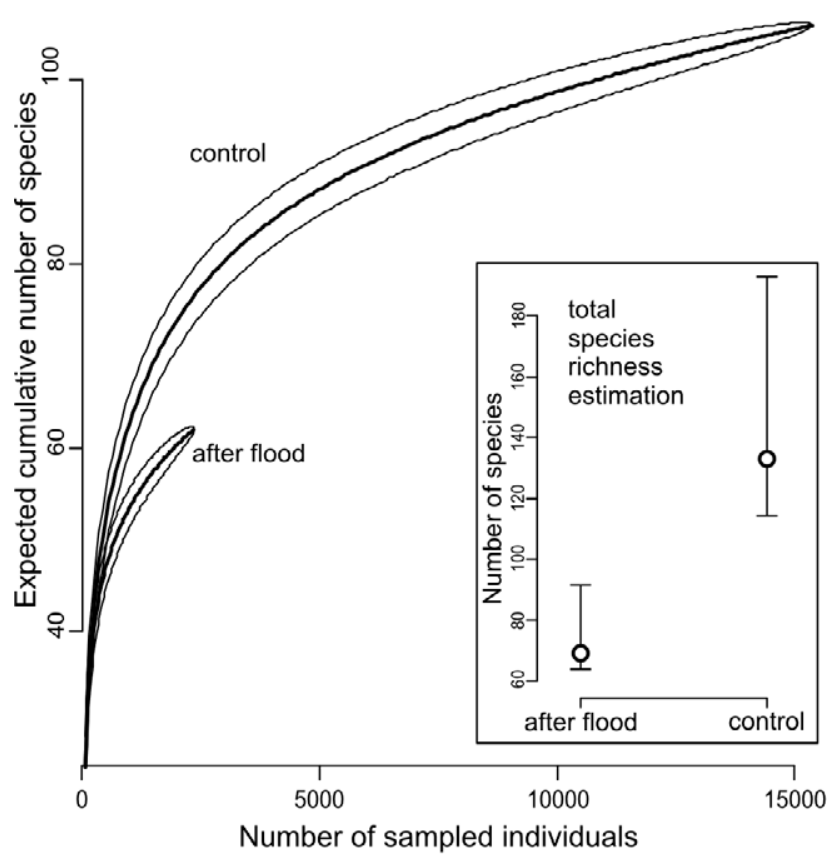

Fig. 3. Expected cumulative number of species of Carabidae (with the SD marked by thin lines) as a function of the number of individuals sampled in After Flood and Control samples. The small panel shows estimated species richness (Chaol estimator), corrected for species absent in samples, with $95 \%$ confidence intervals. 
Exponentiated parameter estimates (with 95\%Cl)

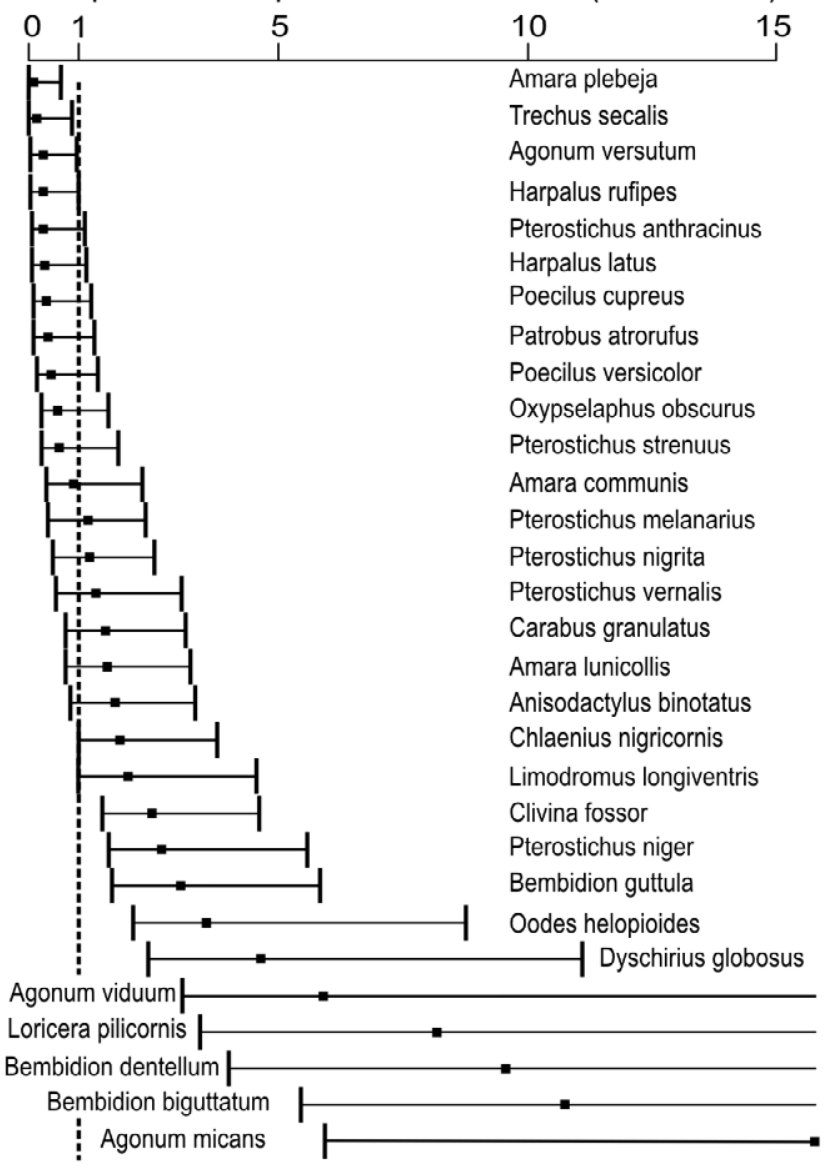

Fig. 4. Exponentiated parameter estimates (with $95 \%$ confidence intervals) of generalized linear models of the effect of flooding on the abundance of 30 species of Carabidae. Vertical dashed line indicate effect size $=1$ (i.e. no effect). Upper bound of $95 \%$ confidence for some of species is not visible as it is of the scale.

\section{Species-specific response to flooding}

Species-specific responses to flooding (i.e. the difference in abundance in After flood and Control samples) varied between species. Only a few species were less numerous in After flood samples [e.g. Amara plebeja Gyll., Epaphius secalis (Payk.)], for some there was no difference in abundance [e.g. Amara communis (Panz.)] and several were more abundant in the samples collected just after floods (e.g. Agonum micans Nic., Fig. 4).

\section{DISCUSSION}

\section{Spatial and temporal variability in the community}

The GAMM revealed that plot had a strong effect on the carabid community, which might indicate that although all the plots were in grassland they differed in, e.g. plant species composition, habitat characteristics (mainly humidity) or management (intensity of mowing). This confirms that carabid communities are very sensitive to even slight variation in habitat characteristics. The highest abundance of carabids was recorded in plot $\mathrm{A}$, which was not mown and the plants were relatively tall. This may indicate a vegetation biomass effect, which con- firms earlier findings that the abundance of epigeic invertebrates is positively correlated with the height of the vegetation (Morris, 2000; Kruess \& Tscharntke, 2002; Hoste-Danyłow et al., 2010). However, it is not possible to exclude that other factors may have had an effect. The number of plots studied is insufficient for a more rigorous analysis of the results, which indicates the need for further research on this topic.

The trends over time in the number of species and number of individuals were nonlinear. The trend in the number of species was humped, possibly because sampling started early in spring and finished in late autumn. These periods can be unfavorable for some species (mainly due to low temperatures) leading to the nonlinear response recorded for the whole community. The total number of individuals caught decreased very slowly from early spring until the end of August and then more rapidly in the second half of the year, probably due to a decline in the recruitment of young individuals to the overall population.

\section{The effect of floods}

The results clearly indicate that flooding had a marked effect on the carabid community, but the response of the overall community is somewhat unexpected and contradicts some of our assumptions. First of all, the GAMM confirmed that there is a significantly greater total abundance of carabids in the samples collected in areas after flooding than in the control samples. An inspection of the raw data (i.e. not corrected for the other effects used in the model) of the mean number of individuals in samples collected after floods and control samples shows that there were more in the former than the latter (112 vs. 71 respectively). This is also unexpected, because we assumed that carabids, although likely to be adapted to living in flooded areas, would leave flooded areas and the abundance of the whole community in such areas would be low just after a flooding event. That there was an increase is difficult to explain and the underlying mechanism should be investigated at a smaller spatial and temporal scale. Nevertheless, the increase may result from a fast re-colonization of the plots by individuals from adjacent areas, although a substantial contribution from individuals that survived flooding hidden in the soil cannot be excluded. These results corroborate the conclusions of Ellis et al. (2001) that flooding (both experimental and natural) did not affect the taxonomic richness and increased the number of carabids. What is interesting about our study is the number of species per sample was not affected by previous flooding (see Table 1). So the lack of a difference in species richness per sample but fewer species overall after flooding could (theoretically) be a consequence of a higher variability (i.e. species turnover) in the control samples (i.e., beta diversity). As a consequence distinctly lower rarefied species number for a given number of individuals sampled was recorded in after-flood samples than control samples. The differences in diversity seem to be high, for example, in order to record 62 carabid species in the after-flood samples one 
needs to collect 2,357 individuals but only 930 individuals in the control samples.

\section{Winners and losers following flooding}

The species showed different responses to flooding, some increased in number whereas others almost disappeared after flooding (see also Günter \& Assmann, 2005). While only 2 individuals of Amara plebeja were recorded after floods there were 377 in the control samples, with an average number per sample of 0.10 and 1.74, respectively. In case of Epaphius secalis the pattern was similar, 8 and 529 individuals or 0.38 and 2.45 individuals per sample, respectively. It is likely that those species that respond negatively to flooding will be rarer in areas where the probability of flooding is high. It is also likely that these species will occupy specific microhabitats, a topic that needs to be studied. On the other hand, some of the species were more abundant in the samples collected just after flooding. The average abundance per sample of Agonum micans was 8.33 in after-flood samples and only 0.69 in the control samples. The mechanism of species-specific change in the number after flooding is unknown and we did not address this problem directly. The final outcome could be determined both by species preferences for particular habitats (or types of prey), but the competition between species cannot be excluded. If this is the case then a competitor release effect can result in some competitively weaker species settling in disturbed (i.e. flooded) habitats (but see also Shibuya et al., 2011). Nevertheless, the division of the whole community into winners and losers is a typical effect of disturbance and has been reported before for many taxonomic groups that occur on floodplains of rivers (Ellis et al., 2001) and in other disturbed habitats (Saint-Germain et al., 2005; Skłodowski \& Garbalińska 2007, 2011; Grimbacher \& Stork, 2009; Żmihorski \& Durska, 2011).

\section{Adaptations to flooding}

The increase in abundance after flooding is associated with numerous adaptations that enable Carabids to live on floodplains. The adaptations are mainly body size, dispersal ability and reproductive strategy (Gerisch, 2011). In flooded areas the species that appear early in spring predominate, which enables them to leave the floodplain before the spring floods. The communities of carabids living on floodplains are composed of many species that are good fliers and can easily move to other areas in response to flooding. The ability to swim can be also regarded as an adaptation to flooding (Siepe, 1994). In general Carabids do not swim, however even large species [e.g. Pterotichus niger (Schall.), Poecilus cupreus L., Blethisa multipunctata] occasionally use water surface tension to cross small water bodies. What is interesting is that the direction of swimming is not random as there is clear preferences for dark vertical patches (forest, trees etc., which can act as refugia during flooding) (Siepe, 1994). Several specialist species prefer areas subject to flooding, such as Agonum dolens and Blethisa multipunctata, which hunt springtails, and several species of the genus Bembidion (Zulka, 1994a). Some species, e.g.
Limodromus longiventris, which are well adapted to flooding, commonly decrease in abundance when the incidence of flooding decreases (Zulka, 1994a, b). This is because these species are competitively weaker than other species in non-disturbed habitats (e.g. Januschke et al., 2011). Flooding survival strategies differ in the different species (Dziock et al., 2011). Rothenbücher \& Schaefer (2006) show that the majority of planthoppers and leafhoppers $(70 \%)$ tolerate submersion and overwinter in flooded areas, whereas both spiders $(63 \%)$ and carabids (73\%), which are more mobile, move to safe areas.

\section{Conclusions}

In summary, the results indicate that the effect of flooding is less straightforward than it may appear as abundance in terms of the whole community increases, whereas the rarefied diversity decreases in response to flooding. Moreover, particular species show different numerical responses. Nevertheless, the study showed that flooding plays an important role in shaping carabid communities, which confirms the results of previous studies (Günter \& Assmann, 2005; Tuf et al., 2008). As a consequence, the regulation of the water flow of rivers leading to a reduction in flooding would probably result in quantitative and qualitative transformations of carabid communities (McCluney \& Sabo, 2012).

ACKNOWLEDGEMENTS. We are grateful to P. Jałoszyński and anonymous reviewers for constructive comments on the manuscript. K. Krawczyk kindly improved the English.

\section{REFERENCES}

Andersen J. \& Hanssen O. 2005: Riparian beetles, a unique, but vulnerable element in the fauna of Fennoscandia. Biodivers. Conserv. 14: 3497-3524.

Beyer W., Grube R. \& Pfadenhauer J. 1997: Influence of inundation on epigeous spiders and ground-beetles at riparian sites in the national park "Lower Oder Valley" (Arach.: Araneida, Col.: Carabidae). Verh. Gesell. Ökol. 27: 349-356.

Bornette G. \& Amoros C. 1996: Disturbance regimes and vegetation dynamics: Role of floods in riverine wetlands. J. Veget. Sci. 7: 615-622.

Colwell R.K. 2005: EstimateS: Statistical Estimation of Species Richness and Shared Species from Samples. Version 7.5. http://purl.oclc.org/estimates. Assessed 20 December 2010.

Dziock F., Gerisch M., Siegert M., Hering I., Scholz M. \& ERNST R. 2011: Reproducing or dispersing? Using trait based habitat templet models to analyse Orthoptera response to flooding and land use. Agric. Ecosyst. Environ. 145: 85-94.

Ellis L.M., Crawford C.S. \& Molles M.C. 2001: Influence of annual flooding on terrestrial arthropod assemblages of a Rio Grande riparian forest. Regul. Rivers Res. Manag. 17: 1-20.

GERISCH M. 2011: Habitat disturbance and hydrological parameters determine the body size and reproductive strategy of alluvial ground beetles. In Kotze D.J., Assmann T., Noordijk J., Turin H. \& Vermeulen R. (eds): Carabid Beetles as Bioindicators: Biogeographical, Ecological and Environmental Studies. ZooKeys 100: 353-370.

GIREL J. 1994: Old distribution procedure of both water and matter fluxes in floodplains of western-europe - impact on present vegetation. Environ. Manag. 18: 203-221. 
Grimbacher P.S. \& Stork N.E. 2009: How do beetle assemblages respond to cyclonic disturbance of a fragmented tropical rainforest landscape? Oecologia 161: 591-599.

GÜNTHER J. \& ASSMANN T. 2005: Restoration ecology meets carabidology: effects of floodplain restitution on ground beetles (Coleoptera, Carabidae). Biodivers. Conserv. 14: $1583-1606$.

Hoste-Danyeow A., Romanowski J. \& Żmihorski M. 2010: The effect of management type on epigeic invertebrates and foraging birds in extensively used grasslands of central Poland. Agric. Ecosyst. Environ. 139: 129-133.

JanuschKe K., Brunzel S., HaAse P. \& Hering D. 2011: Effects of stream restorations on riparian mesohabitats, vegetation and carabid beetles. Biodivers. Conserv. 20: 3147-3164.

Jensen K., Trepel M., Merritt D. \& Rosenthal G. 2006: Restoration ecology of river valleys. Basic Appl. Ecol. 7: 383-387.

KoIvULA M.J. 2011: Useful model organisms, indicators, or both? Ground beetles (Coleoptera, Carabidae) reflecting environmental conditions. In Kotze D.J., Assmann T., Noordijk J., Turin H. \& Vermeulen R. (eds): Carabid Beetles as Bioindicators: Biogeographical, Ecological and Environmental Studies. ZooKeys 100: 287-317.

Kotze D.J., Assmann T., NoordiJk J., Turin H. \& Vermeulen R. 2011: Carabid Beetles as Bioindicators: Biogeographical, Ecological and Environmental Studies. Pensoft, Sofia, 573 pp.

Kruess A. \& TscharntKe T. 2002: Contrasting responses of plant and insect diversityto variation in grazing intensity. Biol. Conserv. 106: 293-302.

LuKa H., Marggi W., Huber C., Gonseth Y. \& Nagel P. 2009: Carabidae. Ecology - Atlas. Fauna Helvetica 24: 1-678.

Mccluney K.E. \& SABo J.L. 2012: River drying lowers the diversity and alters the composition of an assemblage of desert riparian arthropods. Freshw. Biol. 57: 91-103.

MorRIS M.G. 2000: The effects of structure and its dynamics on the ecology and conservation of arthropods in British grasslands. Biol. Conserv. 95: 129-142.

Paetzold A., Yoshimura C. \& Tockner K. 2008: Riparian arthropod responses to flow regulation and river channelization. J. Appl. Ecol. 45: 894-903.

Plum N. 2005: Terrestial invertebrates in flooded grassland: a literature review. Wetlands 25: 721-737.

R Development Core Team 2011: R: A Language and Environment for Statistical Computing. R Foundation for Statistical Computing, Vienna, Austria. URL http://www.R-project.org/

Romanowski J., Matuszkiewiecz J., KowalczyK K., Kowalska A., KozŁowska A., Solon J., Bouwma I.M., Middendorp H., REIJNen R., RozemeiJer R. \& Sluis T. van der (eds) 2005: Evaluation of Ecological Consequences of Development Scenarios for the Vistula River. Warsaw, Wageningen, Utrecht $127 \mathrm{pp}$.

Rotenbücher J. \& Schaeffer M. 2005: Conservation of leafhoppers in floodplain grasslands - trade-off between diversity and naturalness in a northern German national park. J. Insect Conserv. 9: 335-349.

ROtHENBÜCHER J. \& SCHAEFFER M. 2006: Submersion tollerance in floodplain arthropod communities. Basic Appl. Ecol. 7: 398-408.

Saint-Germain M., Larrivée M., Drapeau P., Fahrig L. \& BudDLE C.M. 2005: Short-term response of ground beetles
(Coleoptera: Carabidae) to fire and logging in a sprucedominated boreal landscape. Forest Ecol. Manag. 212: $118-126$.

Shibuya S., Kubota K., Ohsawa M. \& Kikvidze Z. 2011: Assembly rules for ground beetle communities: What determines community structure, environmental factors or competition? Eur. J. Entomol. 108: 453-459.

SiENKIEwicz P. 2003: Ground beetles (Coleoptera, Carabidae) of the seasonally flooded meadows in the valley of the middle course of the Warta - qualitative analysis. Baltic J. Coleopterol. 3: 129-136.

SIENKIEWICZ P. \& Konwerski S. 2004: Znaczenie rezerwatu „Krajkowo” koło Poznania dla ochrony chrzązzczy (Coleoptera) środowisk dolin rzecznych. [The importance of the Krajkowo reserve near Poznań for the protection of Coleoptera of riparian habitats] Wiadom. Entomol. (Supl.) 23: 189-191 [in Polish].

SIEPE A. 1994: The "Flooding behaviour" of carabid beetles (Coleoptera: Carabidae) in river floodplains: ecological and ethological adaptations to periodic innudations - I: Swimming. Zool. Jb. Syst. 121: 515-566.

SkŁodowski J. \& GarbalińsKa P. 2007: Ground betele assemblages (Coleoptera, Carbabidae) in third year of regeneration after hurricane in the Puszcza Piska pine forests. Baltic J. Coleopterol. 7: 17-36.

SkıOdowski J. \& GarbalińsKa P. 2011: Groudnd betele (Coleoptera, Carabidae) assemblages inhabiting Scots pine stands of Puszcz Piska Forests: six-year responsem to a tornado impact. Zookeys 100: 371-392.

Thiele H.U. 1977: Carabid Beetles in their Environments. Springer, Berlin, Heidelberg, New York, 369 pp.

TOCKNER K. \& StANFORD J.A. 2002: Riverine flood plains: present state and future trends. Environ. Conserv. 29: 308-330.

Tuf I., Dedek P., Jandová S. \& Tvardík D. 2008: Length of recovery of soil macrofauna communities (Coleoptera: Carabidae, Isopoda: Oniscidea) after an irregular summer flood. Peckiana 5: 65-75.

Walter T., Umbricht M. \& Schneider K. 1998: Datenbank zur Fauna der Auen. FAL, Reckenholz, Switzerland [www document]. URL http://www.admin.ch/sar/fal/aua/.

Ward J.V., Tockner K., Uehlinger U. \& Malard F. 2001: Understanding natural patterns and processes in river corridors as the basis for effective river restoration. Regul. Rivers Res. Manag. 17: 311-323.

Wood S.N. 2004: Stable and efficient multiple smoothing parameter estimation for generalized additive models. J. Am. Stat. Assoc. 99: 673-686.

ZULKA K.P. 1994a: Carabids in a Central European floodplain: species distribution and survival during innudations. In Desender K. (eds): Carabid Beetles: Ecology and Evolution. Kluwer Academic Publishers, Dordrecht, pp. 339-405.

ZULKA K.P. 1994b: Natürliche Hochwasserdynamik als Voraussetzung für das Vorkommen seltener Laufkäferarten (Coleoptera, Carabidae). Wiss. Mitt. Niederösterr. Landesmus. 8: 203-215.

ŻMIHORSKI M. \& DURSKA E. 2011: The effect of contrasting management types on two distinct taxonomic groups in a large scaled windthrow. Eur. J. Forest Res. 130: 589-600.

Received February 10, 2012; revised and accepted June 18, 2012 